\title{
Benefits and costs of a constructed wetland on a Wairarapa dairy farm
}

\author{
J. PRAAT ${ }^{1}$, J SUKIAS 2 , T FAULKNER ${ }^{3}$ and A. BICHAN ${ }^{4}$ \\ ${ }^{I}$ Groundtruth Ltd, 104 Turere Lane, Te Awamutu \\ ${ }^{2}$ National Institute of Water and Atmospheric Research, Gate 10, Silverdale Road, Hamilton \\ ${ }^{3}$ Greater Wellington Regional Council, Masterton \\ ${ }^{4}$ Kaiwaiwai Dairies Ltd, 839a State Highway 53, Featherston \\ jp.praat@groundtruth.co.nz
}

\begin{abstract}
A demonstration wetland was constructed with community support in what was a "wet" 0.75 ha of a Wairarapa dairy farm. This has reduced the level of nitrate-nitrogen leaving the farm, and has also added biodiversity to the farm and the region. Comparison of nitrate-N levels of water flowing in and out of the wetland over three months show this water quality benefit may reduce farm $\mathrm{N}$ loss from 14 down to 13 $\mathrm{kg} \mathrm{N} / \mathrm{ha} / \mathrm{yr}$, which equates to an ongoing reduction of around $7 \%$ for a one-off investment of at least $\$ 55000$. However, other contaminants such as dissolved reactive phosphate may not necessarily be reduced, while counts of Escherichia coli increased in wetland outflow. This project required a range of skills unlikely to be available to an individual farmer without wider community support but now that the wetland is established it will demonstrate what is possible when more complex solutions are implemented for nutrient loss mitigation.
\end{abstract}

Keywords: dairy farm, constructed wetland, denitrification, nitrate- $\mathrm{N}$, water quality, biodiversity

\section{Introduction}

The term "nutrient loss mitigation strategies" is used widely among rural and urban communities. Funding from the Ministry for the Environment's (MfE) Fresh Start for Freshwater Clean-Up Fund in 2012 to the Wairarapa Moana Wetlands Project has enabled the demonstration of a number of nutrient loss mitigation strategies on farms in the Lake Wairarapa catchment. These have been focused on improving the quality of water entering Lake Wairarapa and enhancing biodiversity across farmland and the edge wetlands. Projects are co-funded by a range of partners, including landowners, and administered by the Greater Wellington Regional Council. In particular, on-farm works are cofunded by MfE and farmers, with the level of support from the fund increasing in proportion with the level of off-farm benefits.

The Lake Wairarapa area has an extensive drainage network into the lake, totalling around $1300 \mathrm{~km}$ in length. One project in this area has been the construction of a wetland on a dairy farm adjacent to a remnant kahikatea stand. In combination these areas add significant biodiversity to the farm and the region as well as improving water quality by removing contaminants from farm drainage water.

Wetland areas provide an efficient system to remove contaminants from drainage water, particularly nitrate through denitrification. and allow time for any sediment to settle out. Left unchecked contaminants such as nitrogen and phosphorus enter waterways through groundwater, surface runoff and direct application stimulating algal growth which degrades water quality.

\section{Methods}

A crucial component of the landowner engagement has been the technology transfer component of the project. Farmers volunteered to be involved in the project and their farms were assessed during a 2-3 hour visit including a quick tour of the farm. Potential onfarm projects to improve the quality of water leaving the farm and biodiversity on-farm were identified and discussed. A number of these on-farm projects were selected for further development and scored for their feasibility, interest, budget, and benefits

\section{Construction of wetland}

During the farm tour in July 2013 a "wet" area was identified as evidenced by rushes, poor pasture species, pugging damage and surface water in some places. Subsequent survey work in February 2014 showed that a drain with permanent water flow to the north was slightly elevated $(0.1 \mathrm{~m})$ relative to the north edge of the wet area. A flow of 60 litres/second was measured at the time in the drain, which was considered normal flow by the farm manager. A compacted layer of gravel was found approximately $0.6 \mathrm{~m}$ below the soil surface of the wet area. On this basis it was decided to look more closely at constructing a wetland in the already wet area. Key considerations in design of the wetland included attaining a nominal flow of between 11.5 and 15.4 litres/s/ha of wetland. Achieving a stable uniform flow will remove twice the nitrogen from the water as compared with non-uniform flow (Tanner \& Kadlec 2013) and that redirected flow from the feeder drain 
could be returned downstream to the original drain system. Further detail of design considerations are published elsewhere (Praat et al. 2015).

A $200 \mathrm{~mm}$ diameter pipe was installed in August 2014 to convey water from the drain to headworks. The headworks consisted of a 500 litre plastic tank with several exit holes of different diameters and a gauged overflow height to maintain a head or height of water above the inflow to the wetland. In this way water flow could be calibrated for either 1, 3 or 10 litres per second. Earthworks transformed 0.75 ha of wet pasture to a wetland with about 0.5 ha of open water. Plants suited to a wetland water depth of $300 \mathrm{~mm}$, including raupo (Typha orientalis), lake clubrush (Schoenoplectus tabernaemontanii) and rautahi (Carex geminata), were planted in October 2014. The balance of the area was planted with a mixture of flax (Phormium tenax), karamu (Coprosma robusta), manuka (Leptosperum scoparium) and cabbage trees (Cordyline australis).

The wetland featured three connected but separate areas providing a serpentine flow path of water down $6 \mathrm{~m}$ wide bays (see Figure 1). These bays run back and forth across the gradient to slow down water flow, and maximise residence time and water treatment. The wetland is well vegetated to give good dispersion and even water flow and minimise channelisation or dead- zones, and is fenced to exclude livestock. An additional feature of this project was the restoration and protection of an area of large kahikatea and totara (100+ years old) which was overgrown with blackberry.

\section{Analysis}

Water samples

Monthly water sampling has been carried out at Kaiwaiwai between January 2015 and May 2015. Samples were sent to Hill Laboratories within 24 hours of sampling for standard water analysis. Data from the January sampling is not shown as the outflow was submerged and difficult to sample. A single sample was taken at each date at the inflow and outflow of the wetland.

\section{OVERSEER $\mathbb{R}$}

In a wetland, anaerobic bacteria in the sediment convert the nitrate-nitrogen in the water to nitrogen gas which is then released into the atmosphere. This is known as denitrification. Overseer was used to estimate the nitrogen $(\mathrm{N})$ removed in a wetland by this process. This depended on the size of the contributing catchment, the size of the wetland and how well the wetland is functioning. We assumed that about $1 / 6$ of the flow was redirected from the drain, that the drain catchment is

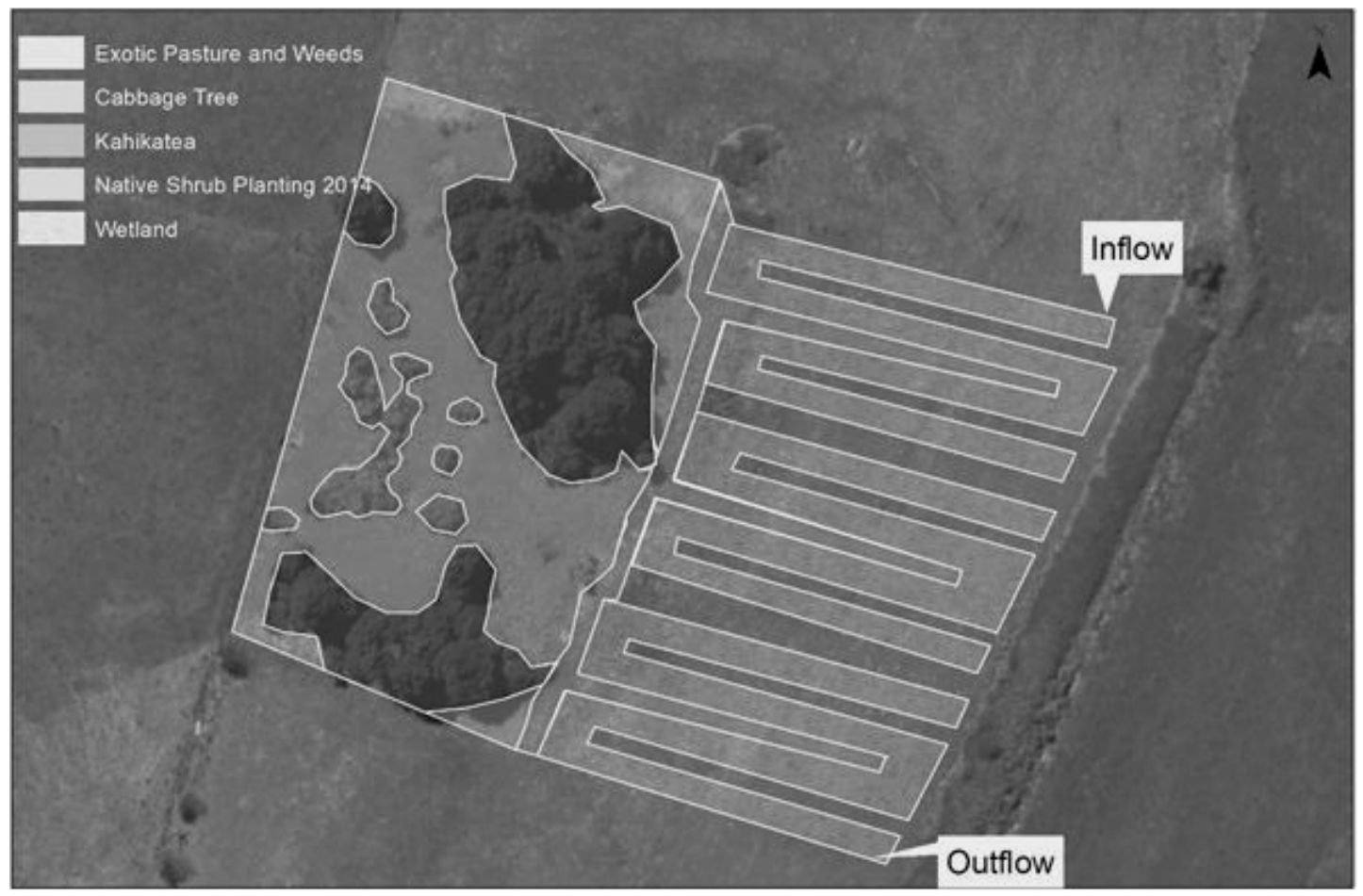

Kaiwaiwai Wetland

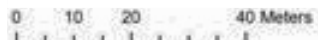

Figure 1 Map showing location remnant bush and design of wetland with entry and exit points. 
ca. 300 ha and that the wetland was 1 ha (minimum size available in Overseer) and that the wetland is efficient (constant flowing shallow water, no dead zones).

For comparison, the quantity of nitrate- $\mathrm{N}$ actually being removed by the wetland can also be calculated from the water quality and water flow data from the wetland. Flow rate into the wetland was 10 litres/sec for the March, April and May (or $315360 \mathrm{~m}^{3}$ annually). When multiplied by the difference between inflow and outflow concentrations, the actual nitrate-N removed can be calculated.

\section{Results and Discussion}

Selected results from each sampling time are listed in Table 1. Full results are available from the corresponding author. Results from the February and March samples shows that virtually $100 \%$ of nitrate in the drainage water entering the wetland was removed, indicating that the wetland could have removed more nitrate- $\mathrm{N}$ than provided by the 10 litres/sec flow rate. Significant rain fell before the April sampling $(20 \mathrm{~mm}$ in 2 days prior), as the first autumn rain event after a dry summer (little or no rain since early December). Nitrate levels in the drain, which are reflected by inflow readings, increased from around $0.8 \mathrm{~g} / \mathrm{m}^{3}$ in previous samples up to $3.6 \mathrm{~g} / \mathrm{m}^{3}$ in the April 15 sample. This is most likely due to annual autumn flushing of unused nitrates under pasture as well as any plant uptake in the drains being overwhelmed.

Due to effective nitrate removal within the wetland, Total Nitrogen has also been reduced through the wetland on each occasion. Dissolved Reactive Phosphate (DRP) decreased in February, March and April but increased in May. The increase in DRP in May is likely to be related to senescence of aquatic plants especially raupo with cooler May temperatures. Average air temperature for March, April and May was 16.0, 13.8 and 10.9 respectively. Levels of E. coli (Escherichia coli) showed marked increases in the outflow as compared with inflow, most likely due to increase in water temperature in the wetland relative to the drain, given the relatively shallow and open, slower moving water of the wetland and increased birdlife.

\section{Costs and aesthetics}

The construction of this wetland was co-funded by the farmer and Ministry for the Environment through the Fresh Start for Freshwater Clean-Up Fund. Greater Wellington Regional Council also contributed to the project. Costs included:

- headworks and pipe installation, \$15000,

- excavation of the wetland $\$ 10000$, approximately $\$ 7 / \mathrm{m}^{3}$ of soil,

- fencing, \$3000 and planting, \$17 000

This adds to a total cost of $\$ 55000$. Additional project management and design was supported by the Cleanup fund. As well as contributing to the cash cost, the farmer has also reduced available grazing area by 0.75 ha, estimated to be have been $9000 \mathrm{~kg} \mathrm{DM} / \mathrm{ha}$ /year, but as this was summer grazing in a summer dry area, value is estimated to be $\$ 0.25 \mathrm{~kg} D M$ so around $\$ 1700$ of annual grazing foregone each year. Land value is $\$ 32$ 000/ha so possibly \$24 000 lost capital value if a buyer did not value the aesthetic and co-benefits of the wetland and simply assessed grazing area as providing value. The off-farm or co-benefits from a constructed wetland which takes drainage water from the farm include: downstream users receive less contaminants, especially nitrate; and biodiversity benefits accrue to the surrounding area as the area becomes a refuge for birds, fish and insects. Hawks, shags, pukekos, herons and ducks frequent the wetland and the adjacent stand of native bush. Eels and koura and most likely other fish can be found close by, and frogs were a notable feature in the wetland during the summer.

Overseer analysis estimated that $\mathrm{N}$ loss from the farm will be reduced by $273 \mathrm{~kg}$ of N per year by the wetland. At a cost of at least $\$ 55000$ this equates to a capital cost of $\$ 201 / \mathrm{kg} \mathrm{N}$ which is comparable with other methods of reducing farm nutrient losses from a landuse change. For example in the Taupo catchment values of around $\$ 400 / \mathrm{kg}$ N retired have been used (Rennie 2012).

Table 1 Comparison of the quality of water entering and leaving the Kaiwaiwai Wetland

\begin{tabular}{|c|c|c|c|c|c|c|c|c|}
\hline \multirow{3}{*}{$\begin{array}{l}\text { Date } \\
\text { Flow (litres/s) }\end{array}$} & \multicolumn{2}{|c|}{05 Feb 2015} & \multicolumn{2}{|c|}{10 Mar 2015} & \multicolumn{2}{|c|}{15 Apr 2015} & \multicolumn{2}{|c|}{07 May 2015} \\
\hline & \multicolumn{2}{|c|}{3} & \multicolumn{2}{|c|}{10} & \multicolumn{2}{|c|}{10} & \multicolumn{2}{|c|}{10} \\
\hline & In & Out & In & Out & In & Out & In & Out \\
\hline Total $\mathrm{N}\left(\mathrm{g} / \mathrm{m}^{3}\right)$ & 1.49 & 1.2 & 1.2 & 0.45 & 4.1 & 2.8 & 2.5 & 1.63 \\
\hline Nitrate-N $\left(\mathrm{g} / \mathrm{m}^{3}\right)$ & 0.86 & $<0.02$ & 0.81 & $<0.02$ & 3.6 & 1.88 & 2.1 & 0.76 \\
\hline $\mathrm{DRP}^{\#}\left(\mathrm{~g} / \mathrm{m}^{3}\right)$ & 0.063 & 0.024 & 0.048 & 0.022 & 0.025 & 0.016 & 0.027 & 0.063 \\
\hline E. coli cfu/100ml & 6 & 20 & 33 & 360 & 110 & 1300 & 81 & 700 \\
\hline
\end{tabular}

\# DRP = Dissolved Reactive Phosphate 
Table 2 summarises nitrate-N removal for March, April and May. Actual nitrate-N removal capacity was reflected by April and May results as in March no nitrate- $\mathrm{N}$ was detected in the outflow. Comparison of April and May results shows how denitrification is affected by temperature with less $\mathrm{N}$ removed in cooler conditions (Bachand \& Horne 1999; Dawson \& Murphy 1972). The wetland will take $1-2$ years to become fully established, and is expected to maintain itself with wetland plants growing and dying in an annual cycle. Organic matter will accumulate in the base of the wetland and continually convert nitrate to nitrogen gas. Water sampling will be continued so that wetland capacity for $\mathrm{N}$ removal can be assessed through an annual cycle.

Total annual farm $\mathrm{N}$ losses were estimated by Overseer to be $6203 \mathrm{~kg} \mathrm{~N}$ which equates to an average farm loss or leaching value of $14 \mathrm{~kg} \mathrm{~N} / \mathrm{ha}$. Therefore a reduction of at least $443 \mathrm{~kg} \mathrm{~N}$ from the total farm losses is required to reduce the overall farm losses by $1 \mathrm{~kg} / \mathrm{ha}$ (down from 14 to $13 \mathrm{~kg} \mathrm{~N} / \mathrm{ha}$ ). The results indicate the existing wetland has the capacity to do that. However, larger systems would be required to handle the full flow and significantly reduce overall losses from the farm.

\section{Conclusion}

Constructing a viable wetland was a reasonably complex project, but valuable in terms of providing an on-going improvement in the quality of water exiting the farm and increasing biodiversity on the farm and wider region. This project was successful due to a combination of engineering and practical farm

Table 2 Nitrate-N removal from Kaiwaiwai Wetland from March to May 2015

\begin{tabular}{lccc}
\hline & Nitrate-N $\left(\mathbf{g} / \mathbf{m}^{3}\right)$ & $\begin{array}{c}\text { Reduction in } \\
\text { farm N exports }\end{array}$ \\
\hline In & Out & kg N/yr \\
\hline March & 0.81 & $<0.02$ & $252^{*}$ \\
April & 3.6 & 1.88 & 542 \\
May & 2.1 & 0.76 & 422 \\
\hline
\end{tabular}

* possibly underestimate of removal capacity as no nitrate- $\mathrm{N}$ was detected in the outflow management skills, off-farm support, and a desire to work with sustainable ecological solutions, as well as a willingness to try something different.

While the wetland is exceeding initial expectations in terms of nitrate-N removal, DRP removal may not be sustained and E. coli levels were increased. These results show a wetland is not a silver bullet but could be part of an integrated farm plan to mitigate nutrient losses. This project now demonstrates a very visible and tangible action which a farmer can undertake to reduce nutrient loss from the farm and while providing a significant lift in biodiversity. This may prove to be a very valuable asset for farms in the future.

\section{ACKNOWLEDGEMENTS}

Neville Fisher, Operations Manager, Kaiwaiwai Dairies Ltd, Vern Brasell, landowner, Chris Tanner, Scientist, NIWA.

\section{REFERENCES}

Bachand, P.A.M.; Horne, A.J. 1999. Denitrification in constructed free-water surface wetlands: II. Effects of vegetation and temperature. Ecological Engineering 14: 17-32.

Dawson, R.N.; Murphy, K.L. 1972. The temperature dependency of biological denitrification. Water Research 6: 71-83.

Praat, JP.; Sukias, J.; Faulkner, T. 2015. On-farm drainage remediation projects to protect Wairarapa Moana. In: Moving farm systems to improved nutrient attenuation. Eds Currie, L.D.; Burkitt, L.L. http://flrc. massey.ac.nz/publications.html. Occasional Report No. 28. Fertilizer and Lime Research Centre, Massey University, Palmerston North, New Zealand. 7 pages Rennie, R., 2012: Taupo nitrogen trading board opens. Farmers Weekly 26 July 2010. http://www. farmersweekly.co.nz/article/8371

Tanner, C.C.; Kadlec, R.H. 2013. Influence of hydrological regime on wetland attenuation of diffuse agricultural nitrate losses. Ecological Engineering 56: 79-88.

Tanner, C.C.; Sukias, J.P.S.; Yates, C.R. 2010. New Zealand guidelines: Constructed wetland treatment of tile drainage. NIWA Information Series No. 75. http://www.niwa.co.nz/our-science/freshwater/tools/ tile-drain-wetland-guidelines 